RESEARCH ARTICLE

\title{
Women as Actors in Violence against Women: An Analysis of Woman-to-Woman Violence within the Marriage Space
}

\author{
Constance Awinpoka Akurugu*
}

Department of Community Development, SDD-Dombo University of Business and Integrated Development Studies, Ghana.

\begin{abstract}
This article examines violence against women in marriage, and particularly, violence exacted or instigated by women in a relative position of power against less privileged ones, or what I refer to as woman-to-woman violence. This is carried out by paying critical attention to the network of relations and power dynamics between women and men within the marriage space, my designation for the physical space of the home, and the concatenation of relations that characterize marriage in the context of northern Ghana. The article draws on feminist ethnographic data collected in a rural settlement in north-western Ghana. Based on the analysis of my ethnographic data, I argue that as the Dagaaba notion of a family entails more than a nuclear family of wife, husband, and children, critical attention not only needs to be paid to woman-to-woman violence, but also to a broader scope of actors, including other-than-human entities in theorizing marital violence beyond the spouses in this and similar settings. Woman-to-woman violence can be as deleterious, if not more so, as male spousal violence and yet it has not received much attention in studies on marital violence particularly in the contexts of Ghana and sub-Saharan Africa more broadly.
\end{abstract}

Open Access

Citation: Akurugu, C.A. Women as Actors in Violence against Women: An Analysis of Woman-to-woman Violence within the Marriage Space. Gender and Women's Studies. 2021; $4(1): 1$.

Received: July 31, 2020

Accepted: December 22, 2020

Published: January 07, 2021

Copyright: @2021 Akurugu CA. This is an open access article distributed under the terms of the Creative Commons Attribution License, which permits unrestricted use, distribution, and reproduction in any medium, provided the original author and source are credited.

Corresponding author:

Constance Awinpoka Akurugu, Department of Community, SDDDombo University of Business and Integrated Development Studies, Ghana; E-mail:

cakurugu@ubids.edu.gh

\section{Keywords}

Power, woman-to-woman violence, northern Ghana, mysticism, the marriage space

\section{Introduction}

Violence against women, including intimate partner abuse and wife or partner battering, has gained considerable attention across societies in the world due to its pervasiveness and fatal consequences on occasion (see Dobash \& Dobash, 1979; Gelles \& Steinmetz, 1980; Straus \& Gelles, 1986; Johnson, 1995, 2008; Straus, Murray \& Gelles, 2017 for studies in settings in the global north). Similarly, in the context of Ghana, the phenomenon of violence against women has gained significant attention as a result of its prevalence and horrifying nature despite legal provisions prohibiting it (see Ofei-Aboagye, 1994a, 1994b; Coker-Appiah \& Cusack, 1999; Adinkra, 2004; Amoakohene, 2004; Osam, 2004). An analysis of the aforementioned studies draws attention to the horrors of intimate partner violence-physical, psychosocial, and sexual-against women. It is estimated that one in three Ghanaian women has suffered some form of physical male violence (Appiah \& Cusack, 1999). This could be a grave underestimate given that the majority of the women do not report their experience of violence. Yet, lacking in the burgeoning discourses on this subject matter is an empirically grounded analysis of the phenomenon of woman-to-woman violence, violence perpetrated by women against other women, in heterosexual marriage in Ghana and within the specific arrangement of Dagaaba exogamous marriage practices. However, as a result of the multi-faceted webs of relations that characterize connubial relations in Ghana and in the West African sub-region more broadly, it is imperative to pay attention to this form of violence. This article addresses this gap by focusing on women's lived experiences of marital violence instigated and perpetuated by other women in a relative position of power and its implications drawing on fieldwork data collected amongst the Dagaaba people in rural north-western Ghana. This endeavor aims to enhance our understanding of the phenomenon of violence against women so as to combat it for its 
toxic effects on women. However, first, I wish to define violence against women, and the definition in the Convention on the Elimination of All Forms of Discrimination against Women (CEDAW) is useful in this regard. CEDAW (1979) defines violence against women as "any act of gender-based violence that results in, or is likely to result in physical, sexual or psychological harm or suffering to women, including threats of such acts, coercion or arbitrary deprivation of liberty, whether occurring in public or in private life". This definition is attractive because of its open-ended categorization of the perpetrators of violence against women. In this article, gender-based violence includes violence exercised by other-thanhuman ontologies (such as the ancestors, the gods, and witchcraft) against women.

Dagaaba cultural groups in north-western Ghana practice exogamous marriage patterns. This is a marriage pattern where a woman leaves her natal family and the support it gives to live with her husband and his agnatic kin (Kpiebaya, 1991; Akurugu, 2019). Marriage amongst the Dagaaba people and the patrilocal residential pattern put women in a distinctly subservient position. This subordination combines with the normative requirements of women to put up with all forms of behavior, including abuse without exposing the husband and his family to outsiders and to evil people who may use supernatural power to harm them. These constraints predispose women to various forms of violence-physical, emotional, and psychological. Furthermore, a woman in marriage finds herself in a network of relations, the marriage space, which normatively should, but does not always protect her interest. The marriage space is my designation for the physical space of the home and the multi-faceted networks of relations that characterize marriage unions in the Dagaaba settlements and across northern Ghana. This concatenation of relations constituting the marriage space includes actors such as the woman in marriage, her husband, co-wives, the parents-in-law, sisters- and brothers-in-law, and all the children within the marriage, in addition to the husband's uncles and aunts. These actors, and a woman's relationships with them, are crucial to the success or otherwise of a marriage. But more importantly, these webs of relations, whilst they constitute a potential network of support for the woman in marriage, may also engender or instigate violence against her. Also, within this space and actively involved in each marriage union are other non-human agents perceived to be paranormalthe ancestors, witches, and magic holders (Akurugu, 2019; 2020. Also, see Akurugu, 2017 for a detailed account of the marriage space and the way the actors contribute to the success or failure of each marriage union). By analyzing the dynamics and the actors within this space, I intend to uncover the performative relations of power in Dagaaba marriage practices and how these engender violence for women. The rest of the article is divided into four sections. In the first section, I examine discourses on spousal violence to develop a context for my analysis. This is followed by an analysis of the research methodology and study site. Thirdly, I discuss my research findings on marital violence and in the final part, I examine the implications of the forms of violence to emerge for theorizing violence against women.

\section{Theorizing Violence in Marriage}

Globally, studies on violence against women in various forms have abounded due to the upsurge in interest in the topic since the 1970s. Within the home, the discourses have often focused on intimate partner relationships, such as marriage and cohabitation (Gelles \& Steinmetz, 1980; Gelles, 1985, 1997; Kurz, 1989; Johnson, 1995, 2008; Tjaden \& Thoennes, 2000; Watts \& Zimmerman, 2002). Straus and Gelles have written extensively on the issue of partner violence in the United States of America (USA), and in the United Kingdom (UK); a groundbreaking text of its time was Dobash \& Dobash's (1979) Violence against Wives. These studies have focused on men-to-women and women-to-men violence reported in national surveys, police reports, shelter/refuge records, and the media. As a result of this focus, theorizing has often concentrated on the couple, eliding the network of relations that engender violence against women in marriage, particularly in contexts like Ghana and West Africa where complex webs of relations characterize marriage unions. For most of them, based as they are on data from parts of the global North, this focus on the marital partners is understandable, since the main actors in a marriage in most of those societies are the couples. This is because the broader network of relations is less useful to theorizing marital violence in most urban settings across sub-Saharan Africa and in contexts in the global north in-as-much-as the emphasis is on the marital couples in those areas.

In Ghana, marital or partner violence has also been widely researched, highlighting the significance and pervasiveness of violence against women in this context. Nonetheless, as I 
examine below, none of these writers highlight the deleterious effects of woman-to-woman violence. For instance, Ofei-Aboagye's (1994a, 1994b) studies are some of the earliest to draw attention to the normalized violence against women in Ghana. Many other studies on gender-based violence in Ghana have drawn attention to the horrors of domestic violence, focusing mainly on male spousal violence against women. Amongst these, a comprehensive study, and one that has been instrumental in activities culminating into the passage of the Domestic Violence Act 732 in 2007, is a collection edited by Coker-Appiah and Cusack (1999). The essays in this collection are based on a nationwide survey of various forms of violence-physical, psychological, and resource-related-against women and children throughout Ghana. One noteworthy finding in this report is not only the pervasiveness of male spousal violence, but also its normalization by duty bearers such as women leaders, educationalists, and social workers. Despite the scope of their study, Coker-Appiah and Cusack do not pay attention to violence which is exercised by women against other women. However, this is an important gap and requires careful attention, particularly in northern Ghana, given that woman-to-woman violence is pervasive and exerts consequences on women's experience of marriage. A recent comprehensive study on the problem of domestic violence in Ghana is the report produced by the Institute of Development Studies (IDS), Ghana Statistical Services (GSS) and associates (2016). This report examines the incidence of, attitudes towards, and consequences of domestic violence in Ghana. It also discusses the effectiveness of the institutional structures such as the Domestic Violence and Victims Support Unit (DOVVSU) of the Ghana Police Service working in the area of violence against women and men. It argues that in 2015, about 28 percent of women experienced domestic violence of various sorts in Ghana. Also emerging from this report is the normalization of violence against women in Ghanaian society. For instance, according to the report, 23 percent of the women interviewed thought wife beating was acceptable, whilst 13.8 percent of the men held this view. This situation leads the authors to project that domestic violence in Ghana may persist as a result of deep-seated socio-cultural practices that hold women responsible for male violence against them.

In the context of the Dagaaba settlements, the phenomenon of woman-to-woman violence has been similarly under-researched. Anthony Naaeke (2006) is one main scholarly source on domestic violence. Naaeke discusses the issues of gendered power and violence against women, here equated to male spousal violence against women. He examines women's relative subordinate position in Dagaaba societies and how violence against women has been taken for granted in that setting. He suggests that women need to speak up against violence in order to overcome it. Whilst Naaeke acknowledges the role of the pervasive belief in mystical forces in preventing women from speaking about and from challenging violence against them, he nonetheless proposes that this is necessary for development in the Dagaaba settlements. However, as I argue elsewhere, for the majority of Dagaaba women, it would only take ill-advised ones to risk their lives in this way fully aware of the consequences of such actions (Akurugu, 2019, 2020). Naaeke recognizes the complex webs of relations within which women perform marriage in Dagaaba settings. He rightly points out that if these institutions were working effectively, they could serve as women's support systems and bulwark against male spousal violence. He does not however consider the role of these webs of relations in engendering violence against the woman in marriage.

Also, in line with the national statistics, in the context of the Upper West Region, including in Dagaaba settlements, male spousal violence against women is pervasive. Representative statistics on the incidence as well as the prevalence of domestic violence are unavailable for the region. However, statistics from DOVVSU of the Ghana Police Service in the Upper West Region collected in 2020 shows that in 2018, the total number of reported cases of male spousal violence against women was 337. This figure increased to 390 in 2019. It is instructive to note that these figures represent a substantial understatement of the situation of violence against women in the Upper West Region as most instances of violation against women go unreported (Amoakohehe, 2004). What is emerging from the discussion here is that existing discourses on spousal violence have tended to focus primarily on male spousal violence against women. The focus on male spousal violence is surely attributable to its pervasiveness as well as to the publicity it attracts in public discourses in Ghana. However, given the multifaceted webs of relations that characterize marriages in rural Ghanaian societies, this elision risks obscuring an important component of marital violence, namely woman-to-woman violence. 
I examine theories of couple violence even as I acknowledge that the contexts of the theories -in the USA, UK, and Canada-vary markedly from the rural northern Ghanaian contexts of my study. Notwithstanding this, the accounts provide insights into the nature of intimate partner violence upon which I have built my empirical analysis. Two main sociological theories of partner violence have been identified: family violence and the feminist perspectives (Straus, Gelles \& Steinmetz, 1980; Kurz, 1989; Johnson, 1995). According to the family violence perspective, wife abuse occurs as part of a series of categories of violence, including child abuse and sibling abuse, that happens within the family unit (Straus et al., 1980; Straus \& Gelles, 1986). For Straus and Gelles, all family members are potential perpetrators, as well as victims, of violence. Women are as likely to initiate violence as men and, therefore, there is no significant gender asymmetry regarding perpetrators and sufferers of violence (Straus et al., 1980; Johnson, 1995). However, the feminist perspectives disagree with this view. The proponents contend that gendered inequalities and power relations between women and men are at the core of spousal violence (Dobash \& Dobash, 1979; Kurz, 1989). Thus, in most cases, women bear the brunt of partner violence. For advocates of this approach, male violence towards women is one means of exercising control over women (Kurz, 1989; Dobash \& Dobash, 1979; Johnson, 1995). Within this tradition, the Power and Control Wheel developed by Pence and Paymar (1993) provides a graphic representation of the strategies a violent male partner may deploy to exercise control over a female one. The perpetrator employs various forms of abuse, such as denying women access to productive resources, threatening to take their children away, and humiliating them. Although the main focus of my analysis here is not male perpetrators, the exemplars I discuss have significant resonance with this approach.

These theories shed light on an issue previously considered private-husband violence towards wives. Nonetheless, in contexts outside the global North, particularly in contexts in rural northern Ghana, marital relations are part of a broad network of family relations. Without paying attention to the other actors in that web, it is difficult to fully grasp the nature of violence against women within marriage. In this article, I extend the frame by focusing on violence amongst women within the marriage space. This is not to minimize the harmful effects of male spousal violence in the male-dominant Dagaaba settlements, but to draw attention to an equally worrying aspect of violence against women in marriage, which has been ignored for the most part in the discourses on violence. I refer to this form of violence as "woman-to-woman". By woman-to-woman, I refer to the acts of women's violence against women-psychological, economic, and physical—visited by women in the position of power and authority on women in relatively less powerful positions in a heterosexual marriage. This is violence initiated and/or perpetrated by women against women. Woman-to-woman violence appears to pervade the entire Ghanaian society, in public life, and the domestic space of the home. However, my focus here is the latter and such a way of theorizing is enabled by the specific arrangement of Dagaaba exogamous marriage practice. Specific units of analysis in this regard are violence engendered by relations involving mothers-in-law and daughters-in-law, as well as co-wives and other female members of the marital family.

\section{Research Context and Methodology}

This article draws on data from residential ethnographic fieldwork which was gathered from August 2013 to August 2014 on gender and power relations in marriage in a Dagaaba settlement called Serekpere. During the study, I carried out in-depth participant observation and recorded detailed fieldnotes on a daily basis. In addition, I was deeply immersed in the life-worlds of my study participants. To complement my participant observation data, I conducted 54 in-depth, semi-structured interviews with women and men from different socioeconomic backgrounds in the settlement. Serekpere is a small village located on both sides of the main Economic Community of West African States (ECOWAS) road. Serekpere has an estimated population of 1,100 . It is about $10 \mathrm{~km}$ away from Nadowli, the administrative capital of the Nadowli-Kaleo District of the Upper West Region of Ghana. In Dagaaba settlements and indeed, throughout rural northern Ghana, both quotidian and ritual lives are deeply intertwined with events perceived to be happening in the supernatural realm. Every incident, good or bad, is believed to have mystical causes. ${ }^{1}$ Crop failures, deaths, and sicknesses are believed to be the consequences of punishment exacted by the ancestors or 'missiles' sent by evil persons from within the inner core of the family to cause harm. As a result of the pervasiveness of belief in the supernatural power, any woman in marriage who 
is abused is expected to protect the husband and his family from mystical harm by accommodating rather than resisting or exposing the family by reporting such horrendous acts to the police.

I employed a feminist ethnographic approach to conduct this research. Feminist ethnography draws on key elements of both ethnography and feminism, including experience, empathy, and the principles of equality in addition to participant observation to investigate matters that relate to women (Clifford \& Marcus, 1986; Stacey, 1988; Skeggs, 2001). Feminist ethnography thus presents us with opportunities to conduct research that is experience-based and also recognizes women's experiences as the basis for legitimate knowledge production. It enables the researcher and the researched to enter into partnership and collaboration. In the end, the knowledge produced reflects the experiences and aspirations of the research participants. It thus offers voices to women to tell their stories. These feminist ideals inspired the larger research from which data for this article was extracted. I participated in a variety of activities that are significant to the day-to-day lives of my research participants within family and community spaces. I worked with families, individual women, and the entire community (and this was by taking part in and/or observing communitywide social activities, carrying out a community forum and interviewing both male and female community leaders). Some of the activities I participated in included traveling with women, individuals, and collectives, to remote farm sites to gather wild vegetables and/or to cultivate plants. It also included accompanying individuals and groups of women to other settlements to attend, as well as participate in community-based, funeral ceremonies. The trips became an important source of data. I also spent time at the market place in the village on market days (which falls on every 6th day) and on non-market days. Nonetheless, the women shared with me sensitive information when I was alone with a woman on the farm and away from the village where there was no risk of other people eavesdropping on us. Most of the time our conversations centered on issues such as violence against women, male-control over decision-making processes, sexuality, and marital violence. These conversations generated very rich data and in what follows I draw on this. ${ }^{2}$

The data analysis process was iterative, feeding back into the research as the fieldwork continued to develop (Hammersley \& Atkinson, 2007). At the end of the fieldwork, I read through all the participant observation data and the interview transcripts, and using the highlighting function in word, I highlighted the recurring themes (see Ryan \& Bernard, 2003; Hammersley \& Atkinson, 2007). This permitted me to gain a deeper understanding of the data, and to draw the emerging themes out. As the main themes were becoming evident, I began to sift through the data, adding brief annotated notes. I wrote the emerging themes on 'post-it' note pads and pasted these on the wall, paying attention to how they relate to each other and the patterns that were emerging. I grouped related indexes to form overarching themes and labeled these appropriately. In the final stage, I conducted a thematic analysis, paying attention to the interrelationships between the various concepts and themes that emerged from my analysis and identifying linkages to my research questions and the theoretical framing at this stage. Under each of the themes, I copied and pasted from my data some of the most relevant quotes and narratives, referencing appropriately so that I could easily trace the source. During the data analysis and discussion, the themes and the quotes were useful in helping me structure the article and also in tracing similar texts by simply using the keyword search function in the fieldnotes interview transcripts and the quarterly report folders.

In contemporary Serekpere, descendants of the same patrilineal ancestor live together in large units. The houses are divided into smaller parts called zaga (compounds), and brothers, fathers, sons, uncles, and nephews often share these units. Most of the homesteads are constructed with mud, with an exception of a few, and these-the ones constructed in modern Ghanaian architectural design-are situated along the trunk road near the center of the settlement. Typically, a house contains the head of the family, often the oldest male with his wives and children. Normally, mothers and daughters-in-law live and work together on the family farm, and, in most instances, they also cook and eat together. Within a household, the mother-in-law, decma, literally meaning "mother of the house", and the daughter-in-law, despoge, "woman of the house", perform home management tasks. Customarily, the derma is the overall manager of the home. If she is physically active, she goes to the farm together with her daughters-in-law to sow seeds and harvest the crops. In addition, she may burn charcoal and/or harvest wild vegetables for sale to generate a 
personal income in the off-farm season or tend a small personal rice field in the farm season. The derma is in charge of selling the family farm produce, though she is accountable to the male head of the family, even if he is her son. Within the household, her roles include appropriating proceeds from pito, mostly brewed by her daughter(s)-in-law. In turn, it is her responsibility to provide money to purchase soup ingredients and detergents. The daughterin-law, the deepoge, just like her mother-in-law, takes part in the farm work and in carting the produce home. She is in charge of processing the farm produce for storage. The daughter-inlaw is also in charge of preparing zonkoo, which is the name given to the main meal that is taken to the farm to feed the workers. According to my research participants, both women and men, any woman who delays the zonkos may be beaten on the farm and observers will understand why this is happening. During my fieldwork, it was common for women to say they were running late with the zonkoo and were at risk of being beaten on the farm, or to caution other women that any delay could elicit such a beating.

\section{Results and Discussion: Woman-to-Woman Violence in the Marriage Space}

[...] let's say I want to marry her and she refuses and yet she is flirting outside, it is proper that I force myself on her. If I did that, would she flirt again?... once you sleep with her, that is it; if she goes to another man you would charge him ayifiere ${ }^{3}$ to purify her otherwise she would get $m o r^{4} \ldots$ she wouldn't dare, if I went to the court I would say it is true, she is my late brother's wife and yes, I raped her. Now, you give me back my bride price and let her not step foot in my house. You know, other women are roaming about, have I raped any of them [laughs]? (Kabiebayo, aged about 74).

This opinion was expressed by a community leader in an interview in relation to forced widowhood marriage-marrying a widow by forcibly sleeping with her. In this quote, Kabiebayo expresses the idea of possession, that a man is in charge of his late brother's widow and thus can trespass her body without sanctions because any legal sanction would attract a counter sanction in the form of dismissal from the marital home. If a remarried widow seeks sexual pleasures elsewhere, she risks being punished by the ancestors in the form of attracting mooro. The combined effect of power exercised by men and the supposed power of the ancestors can be seen to be at work-exercising control over women. The significance of this view is further appreciated if we consider that the speaker, Kabiebayo, is a leader-a tendaana - customarily in charge of the community and charged with protecting both women and men. From this viewpoint, it may be difficult for the women to count on him for support in the case of forced widowhood marriage. I have chosen to begin this section with this quote to signal the combined role of male power and the virilocal residential pattern in engendering violence against women. Furthermore, I seek to draw attention to the supernatural dimension of marital violence and the apparent conspiracy by men and the ancestors against women in the form of mooro, in order to demonstrate the complexity of the issue of violence and power within Dagaaba marriage.

In this section, I examine marital violence as I encountered it in Serekpere, and I focus mainly on woman-to-woman violence. During my fieldwork, this form of violence was not uncommon. Indeed, quite the opposite: it was regularly discussed and even joked about in everyday conversations on farms or whilst traveling with local women to funeral or market in another settlement. ${ }^{5}$ However, since this form of violence tends to be more psychological than physical, it was not common to observe it first-hand. Consider this entry from my fieldnotes, as Albert (aged about 37), one of my research participants, and I discussed the exploitation of women by other women in the position of power: "concerning incomegenerating activities, he informed me that the woman [Lisa] brews pito but 'the pito and its proceeds belong to her mother-in-law, she [Lisa] is like a maid-servant to her mother-in-law'". This was a damaging situation for Lisa. I return to Lisa's experience of violence exacted by her mother-law-in and her husband shortly, but I wish to underscore here that her situation was not an isolated one. Many of the women I worked with, both young and old, often described (sometimes unsolicited) their experience of violence at the hands of their mothersin-law, co-wives, and sisters-in-law sometimes amidst tears either in the past or at the time of this study. ${ }^{6}$ 


\section{Violence against women perpetrated by men}

Nevertheless, male spousal violence against women remained a major source of potential danger to many of the women I worked with. As discussed earlier, male violence against women is pervasive as a part of marital life in Dagaaba settlements and throughout Ghanaian societies (Coker-Appiah \& Cusack, 1999; Amoakohene, 2004; Cantalupo et al., 2006). Throughout my stay in Serekpere, discussion of male spousal violence and the way in which it has been normalized was common. Women often admonished each other against certain utterances or practices that might elicit beatings from their husbands. At the village's marketplace, it was not uncommon for women to say they risked being beaten when they arrived home if they reduced prices of grains belonging to their husbands or male heads of the affinal family that they were selling. A view that underscores the extreme forms of gendered violence and torture, and which also echoes the views expressed in the reports I refer to here, was expressed by Mbabile, a male head of a family. He explained:

In the past our fathers used to drive women out of the marital settlement; they could tie a woman on a log and call her fathers [male members of the natal family] to come and see and if they didn't come early enough by the time they arrived she would have been pushed together with the log into a deep pit and she would die. Yet there would be no problem. They could even open up a woman's legs and tie them apart and then put grains into her vagina for fowls to eat and nothing would happen. But with the arrival of modern Ghana, today women now have so much power; more than the men and they are now showing off [laughs] (Mbabile, aged about 78).

The quote above depicts the horrors of male violence against women. This excerpt speaks to women's new position as powerful, having more power than the men who marry and bring them into the settlement and thus "own" them. Most men attributed the source of this perceived power to the postcolonial state of Ghana, with its modern legal institutions outlawing the killing of women as human beings. However, for the state to prohibit the killing of women even if they are suspected of being witches or of using paranormal powers to cause harm within the marriage space is interpreted by some as granting women too much power. This protection of women's right to life seems to frustrate and challenge male authority, which hitherto could be exercised to decimate the lives of women without any sanctions: not even the natal family would be bothered as the quote from Mbabile suggests. The banality of male violence against women looms large in this vignette.

During my ethnographic fieldwork, I observed three instances of male (physical) violence against women, that is, where men beat their wives, and I examine these briefly. In one of these incidents, Martin (aged about 45), a polygynous man with three wives, did not only beat his first wife but actually attempted to throw her, together with a baby in her arms, into a pot of boiling shea nuts. This violence was instigated by the woman's refusal to allow Martin to sell a goat that belonged to her. Interestingly, as Martin often beats his wife without provocation, on this occasion, some of the young men in his family who witnessed the violence, particularly him dragging the woman (with the child in her arms) to the boiling pot, in turn, beat him. Also, Dakorah, aged about 29, married with one wife, frequently beat his wife and, on this occasion, she passed out after he cut her with a machete, leaving a deep wound in her skull. In a third incident, Zunuong (aged about, 40), married with one wife, beat his wife at least three times during the time of my stay in the settlement. Aside from these physical forms of violence, I often witnessed, and was also told about, countless instances of verbal abuse and threats to kill women or eject them from the marital home and denial of food and sex during my fieldwork.

In one disturbing situation that shook nearly the entire settlement, a man gave a poisonous substance meant for killing mice to his wife after a quarrel ensued between them. As the woman, Biili-ma (aged about 32) was angered to her limits by his previous oppressive behavior, she threatened to kill herself and her unborn baby in addition to her two daughters. And, as if to facilitate this process, her husband, a shop keeper in the settlement, gave her the substance. This looming misfortune was only averted when one of the older women within the house realized that Biili-ma had hidden something under a stone and wrestled her for it. She then discovered the poison and took it away. For Biili-ma, this threatened extermination of herself and her children was to bring some relief to her husband who had abandoned her and their children for his girlfriend in another settlement. This is an extreme example, and the violence between mothers-in-law and daughters-in-law, to which I turn, 
rarely reached such exceptional levels. Despite this observation, in one situation, a pot of boiling water aimed by a mother-in-law at a daughter-in-law following a quarrel accidentally splashed on the latter's toddler in her arms, badly scalding his chest and chin.

\section{Power afforded by being an elder woman/mother-in-law}

The relationship between the mother-in-law and the daughter-in-law depends on the power balance-on who occupies the more privileged position in relation to productive resources and on how she exercises this power to gain control and domination over the other. This is not different from other reports on power and violence. ${ }^{7}$ The locus of the violence that characterizes this relationship is primarily home management and economic activities. Customarily, amongst the Dagaaba people, a mother-in-law, decma, is the overall manager of the home. She is in charge of appropriating the proceeds from the sale of pito, mostly brewed by the daughter(s)-in-law, and processing soup ingredients. Whereas some mothersin-law sometimes grant daughters-in-law permission to brew pito for themselves so that they can generate personal income, others do no such "favors". Some daughters-in-law undertake the labor of brewing pito without any personal benefit. Two of my research participants, Lisa (aged about 26) mentioned earlier and Kweku-ma (aged about 24) found themselves in such relationships. Beyond this direct exploitation of women in marriage, my fieldwork revealed instances of mothers-in-law who incited their sons to beat their daughters-in-law. Both mothers and daughters-in-law belong only partially to the marital family due to the exogamous marriage practice that requires the women to marry outside of their clans. But by virtue of her relation as the mother of the daughter-in-law's husband, the mother-in-law tends to be relatively more privileged. In most of the cases I observed, mothers-in-law appeared to wield more power and influence, and some of them deployed these to the disadvantage of their daughters-in-law. I examine Lisa's experience of marital violence, provoked by her mother-in-law and carried out by her husband, in order to create an understanding of this form of violence and the complicity of women in violence against women.

Lisa is a first wife who was violently abducted by her husband (assisted by his friends) in 2006 on her way to the southern part of Ghana to seek menial work. According to her, she suffered frequent beatings by her husband, incited by her mother-in-law. On one occasion, when she was pregnant, Lisa's husband rushed up to her as she was cooking in the kitchen and pushed her head into a pot of boiling soup. This attack was prompted by the fact that she had no longer been able to ignore her mother-in-law's verbal abuse and had retaliated against her. According to Lisa, she had only been rescued on this occasion by customers drinking pito in their compound. Lisa's husband, who was not amused by his wife's "disrespect" for his mother, intervened. In this case, physical violence on the part of her husband was a tool used to force Lisa into compliance with her mother-in-law. Lisa shared with me that if she had someone to fight for her, she would report her husband to the police, even though she envisaged that this could lead to her dismissal from the marital home: "he will ask me to go away but the beating will at least come to a stop". However, she did not want to leave her children behind. The dilemma here is obvious: although Lisa does not want to leave her children behind, she thinks the beating will end only if the police get involved. Reading Lisa's vulnerability, her mother-in-law and husband pounce on her limitations. Lisa is thus controlled, using the constraints imposed on her by exogamous marriage arrangements in Serekpere, which means that her natal family is not nearby and therefore cannot offer support. She was not the only daughter-in-law enduring abuse within the marital space. Some young wives who could not cope with the combined abuse of their husbands and mothers, brothers and sisters-in-law did indeed flee the marital home. In the intimate terrorism form of violence, Johnson (2008) sees male spousal violence as part of systemic patriarchal violence employed to exercise domination and control over a wife or as an expression of anger by the husband. Whereas in Lisa's case, the number of actors and the frequency of abuse may not qualify it as intimate terrorism, it does seem that violence is employed to silence her, and also to express disapproval of her "insubordination" to her mother-in-law. Her mother-in-law may regularly verbally abuse her, stripping her of her dignity before their customers, but Lisa has no right to talk back; to respond is to invite a beating from the mother-in-law's ally, Lisa's husband. What right has a mother-in-law to verbally abuse and embarrass a daughter-in-law publicly but expect her to remain silent? None, but for the power that exogamous practices vest in her and her son. Specifically, I am referring to exogamy's arrangement that requires a woman in marriage to leave her natal family and its support to join her marital family. The latter is supposed to support her, but she cannot always count on this (Akurugu, 2020). Thus, Lisa's staying in the marital space 
without battering is subject to her submitting not only to her husband but also to his mother.

The apparent vulnerability of young women in marriage comes out clearly in what Lisa says in relation to her mother-in-law's temperament. She told me: "my mother-in-law is too quick-tempered; she has no patience, even if you did something good for her, she would still insult you; if there were people [customers] in the house she would still insult you. But I have been advised [by other community members] to have patience in dealing with her because of my children". She adds: "I have really suffered a lot of beatings [...]. At the least provocation, she would insult me and my family members back home and if I could not take it any longer, I would retaliate and then her son would beat me up [laughs wryly]. But now if she starts insulting me, I just walk away from her". Lisa has thus developed a reflective strategy for dealing with the violence, accommodating, and avoiding the conditions-responding to insults with insults - that have the potential to engender injury for her. In the Power and Control Wheel developed by Pence and Paymar, and mentioned above, we see how an abuser may use the threat of taking a woman's children away from her as a means of control. In the case of Lisa, the rules of Dagaaba exogamous marriage are clear. Upon leaving the marriage, the children belong to the husband. Lisa's retaliation-responding to insults with insults - is the cause of her beating. Power is thus being exercised due to resistance as Foucault (1982) notes. But we also see how the mother-in-law and her son deploy power against the young wife, and this shows that some actors may be more privileged in power relations than others. Yet Lisa's attitude provides some prospects for dealing with marital violence. By avoiding the conditions that create fertile grounds for violence, Lisa effectively frees herself from the shackles of battering. Nonetheless, she is not an acquiescent dupe of the combined power of mother and son. In this encounter, she exercises agency, if sometimes with, and at other times without, resistance as its motive. As both accommodators and resistors, women exercise agency (Meyers, 2000). Thus, in choosing to accommodate verbal abuse and humiliation even in the presence of their pito customers, Lisa exercises agency.

To provide another pertinent example, Tina (aged 34), is the only wife of her husband with four children and at the time of this study, she and her husband were living separately from her mother-in-law. In an interview, Tina narrated the difficulties she endured as a young wife when she used to share cooking and eating arrangements with her mother-in-law. She informed me:

we used to cook together and at that time food was scarce. Each time we all went to the farm my mother-in-law would take the lead back home and cook the little food we had and eat everything with her daughters and grandchildren. They would wash all the cooking utensils and pack and lock them up in the kitchen. Then my husband and I would return home to nothing to eat [...] even water, each time I asked her to give me the key to go and open the kitchen and fetch water for use, she insisted that she opens the door for me. I was not permitted to open that [kitchen] door because she feared I would take something else. This experience was very painful and so devastating for me that I cried many times. Even we didn't get water to drink although I was the one fetching it. [...] the abuse became too much for me to bear that I actually got up one day, packed my things and said I was leaving for my father's house and never to return.

The view expressed by Tina echoes those of many young Dagaaba women in marriage, particularly in instances where the mother-in-law is in a relative position of power. Tina performed her role as a daughter-in-law by fetching water for use by not only her husband and mother-in-law but also her sisters-in-law. Furthermore, as custom demands in the Dagaaba settings, Tina often left the farm with an intention to go home and prepare the evening meal for the whole family to share. Unfortunately, her mother-in-law and her daughters did not only usurp this role of the daughter-in-law but actually denied her and her husband food, although they were the most hardworking members of the family. In addition to the above, Tina also informed me that each time she wanted to use cooking utensils belonging to her mother-in-law, she was not permitted by her; instead, her mother-in-law incessantly reminded her to get her set of cookware, despite being aware that she was a young wife who was yet to acquire her own items. To address this deprivation, Tina went to another house and borrowed some cookware until she traveled back to her natal settlement, about $30 \mathrm{~km}$ away from Serepkere, and got cooking items from her mother. This situation of exploitation which some young women found themselves is upsetting for many of them given that the work they carry out on the farms is physically demanding tasks in this hoe-based 
subsistence agricultural setting. Unable to cope with the continuous deprivation of food, verbal abuse and the incessant demands on her time to do farm work and to serve the mother-in-law and sisters-in-law, Tina finally decided to leave the marriage and to return to her natal family where she would be supported, probably. An elderly man from Tina's marital family intervened to dissuade her from carrying out the plan to leave the marriage. Tina informed me that her experience of abuse was nothing compared to what other peers of hers go through: 'I think my situation was far better than other women in this settlement. I have seen instances where the mother-in-law went on a mission to look for another wife for her son because she didn't like his wife or worse still drive the daughter-in-law away, leaving behind her children'. In this case, we see the power of mothers-in-law exercised to the disadvantage of the young daughters-in-law. Lisa's and Tina's mothers-in-law and most mothers-in-law in similar situations appear to wield a considerable amount of power and control, which they deploy to the disadvantage of their daughters-in-law. But not all mothersin-law are that powerful; some suffer emotional and economic abuse and are denied food by their daughters-in-law. This is the case where the power and productive resources are controlled by the daughter-in-law.

\section{Power afforded by being the daughter-in-law or the first or "authentic" wife}

Consider the situation of Pogziema (aged about 69), a widow and a mother-in-law. Pogziema's daughter-in-law had usurped her customary role of selling the farm produce from her. Secondly, Pogziema's daughter-in-law, who is in charge of cooking food for the whole family, scarcely gives her enough food. But because of the danger of being perceived as meddling in and potentially breaking her son's marriage, Pogziema does not challenge her daughter-in-law. Pogziema deals with this form of food deprivation by sometimes sharing her predicament with other women in the marital family. Piiri-ma (aged about 58), a woman from Pogziema's family explained an instance to me in an interview:

[...] one day she went to the farm early in the morning to work and then her daughter-in-law later brought tumpaani and put only three small pieces into a bowl's lead for her. ${ }^{8}$ The daughter-in-law then carried the rest of the food to another shade where her husband was seated to eat with him. Pogziema was deeply hurt by this behavior of her daughter-in-law to the extent that she picked the food and went to Ama's [another woman married into the family] farm to show her how small it was.

This form of food deprivation was widespread in the settlement, and in extreme instances, some mothers-in-law had to start preparing food for themselves, and separately too, although this practice is against Dagaaba cultural norms that require the daughters-in-law to cook for them.

Furthermore, I also uncovered instances where certain favored wives in polygynous marriages prevent (including physically) their husbands from sleeping with co-wives. In one exceptional case which was widely discussed in the village during my fieldwork, Akua (aged about 45), a favored second wife, prevented her senior co-wife from accessing their husband. The preferred wife, referred to as the pogminga sometimes also instigated the beating of their co-wives by the husband (see Akurugu, 2019 for a detailed discussion on the pogminga concept). Related to this, on occasion, these favored wives act to prevent their cowives from benefitting from farm produce or picking economic fruits such as the shea nuts and dawadawa. ${ }^{9}$ Kayinima (aged about 42), a second-time widow-the first husband died and then she remarried another man who also died-shared the deprivation she was subjected to by both her mother-in-law and her senior co-wife in the second marriage.

Our mother-in-law used to give the food-stuff to my senior co-wife to prepare for the family [...] each time she prepared the food, she would put the food in a small bowl for me and two of my children. Anytime I talk about this I feel like crying [...]. The food was not sufficient and so I grew very lean and people in the village used to ask if I was sick.

While women generally occupy a subservient position relative to men in the marriage space, widows in second marriages seemed to have lesser entitlements than the other wives. Thus, by virtue of her position as the "authentic" wife, rather than an "inherited" widow, and drawing on this privilege, Kanyini-ma's co-wife appropriated the family resources to her advantage with the support of their mother-in-law. According to Kanyini-ma, her co-wife abused her on countless occasions and often called her a witch who had used her evil powers to kill her husband and now wanted to exterminate hers too. ${ }^{10}$ This abuse and the stigma attached to the remarried widow was not an isolated case, on the contrary, it was widespread across the 
settlement. Most of the widows reported that the main problems they encountered in the second marriages emanated mostly from the men's "authentic" wives who often abused them by calling the widows ill-fated or insisting that they did not get a share of the farm produce or other productive resources. Pogdaa (aged about 51), another widow who remarried her late husband's brother narrated her nightmare experience in the second marriage:

[...] when this man [late husband's brother] made me his wife, oh come and see at night: she [the man's wife] would insult me until the cock crows. [...] if her husband gets up in the middle of the night to go out and urinate she would start insulting him, thinking he is coming into my room to sleep with me.... and every evening she would call her young daughter and insult her, indirectly insulting me. I was really in agony; I could hardly sleep at night until the husband left the village with her to seek menial work in the south.

The role of women thought of as legitimate wives in exacting violence-psychological and economic-on widows and even other authentic co-wives in relatively less powerful positions can be seen to emerge here. In this sense, the widows are thought of as intruding into the territory of the "authentic" wives in terms of access to the husband and to productive resources, even as widowhood marriage is culturally approved in the Dagaaba contexts. The kinds of violence, women instigating and/or beating up the young wife, in addition to those exacted by women thought of as legitimate wives on widows, and even on other "authentic" co-wives in less powerful situations, seems to represent the way in which women dominate and control the marriage space as well as the economic resources (Dobash et al., 1992). It may also be interpreted as a subversion of the arrangement of living and eating together as mother and daughter-in-law in this exogamous society or as a way of undermining Dagaaba polygyny. For instance, the daughter-in-law or co-wife is aware that to resist these arrangements outright is to risk attracting name-calling and supposed mystical harm. Thus, rather than not allowing a husband to marry another wife, she employs denial of access to the husband and productive resources by a co-wife as a way of protesting against polygyny. In a similar vein, a daughter-in-law who expresses disinterest in cooking for her mother-inlaw risks the same sort of stigma and perceived supernatural harm. Consequently, a woman denying her mother-in-law access to food is to announce to her that the resources belong to her husband and not to the mother-in-law. In this sense, we see the subversion of both the normative arrangements of sharing a husband and productive resources, and of communal living and eating together in this exogamous society. But more importantly, we see power being exercised by women to exact violence against other ones. The particular situation of violence recounted here differs from that in the reports from within and outside of Ghana discussed above. This is because these forms of violence emanate from the complex interrelationships and mystical forces of Dagaaba settlements and this is consistent with my notion of the marriage space as a concatenation of multiple networks of relations.

\section{Conclusions: The Complexities of Gendered Power and Marital Violence within the Marriage Space}

This article focused on the workings of power in various ways, firstly, on how it is deployed by various actors within the marriage space to exercise violence against women, and secondly, on how power, in addition to supposed mystical power forms, pervades daily life amongst the Dagaaba people. Different forms of violence have been shown to have a pernicious effect on women in marriage. Analysis has revealed both violence that is exercised as part of strategies to keep women under control and violence as a systemic issue. Whilst the husband-to-wife violence, I observed, was very much physical and widespread, woman-to-woman violence appeared emotional, psychological, and economic. Nonetheless, the psychological and resource-related violence, I encountered, was no less devastating. Also, given the range of actors and dynamics involved in marital violence within the marriage space, discussion shows that power is not only concentrated in the men or the ancestors and deployed to repress women; it permeates the network of relations that characterize marriage. Power is deployed by women against other women, and in a sense, the notion of power as performatively constituted resonates profoundly in this rural Dagaaba context (Foucault, 1982; Mills, 2003; Butler, 2011; Akurugu, 2019). Women can be perpetrators of violence and not just victims, and power deployed by women, like that which is exercised by men, can be harmful in its workings. Whereas some forms of power may be 
exercised by women to assert authority and control over other women, it can be argued that some of it is deployed to subvert Dagaaba normative institutions and arrangements governing marriage and social life more broadly. The existing theories of intimate partner violence - the family violence and the feminist perspectives-are productive in facilitating our understanding of marital violence, but only between the partners. Considering the range of actors and dynamics involved in the marriage space, they are inadequate in explaining the form of violence under consideration. As a result of the nested webs of relations that characterize marriage in the Dagaaba and similar exogamous groups, to be able to understand marital violence so as to combat it, attention needs to be paid not only to couple violence but also to woman-to-woman violence, and to the network of relations within the marriage space.

The dynamics that govern marital relations in the matrilineal settings in the southern part of Ghana differ markedly from those in northern Ghana. This is because in the matrilineal settings, customarily, the marital couples live in a residential place provided by the maternal uncle of the woman. Based on this normative arrangement, it is often argued that women's experience of marital violence and power are different (Bleek, 1976; see also Ogunyemi, 1997). Also, unlike within the patrilineal societies, power, authority, and property inheritance in the matrilineal settlements are passed to the male members of the matrilineage, for instance, to a mother's brother. It will be productive for future research to explore the power dynamics and women's violence against women in those settings. This will enable an indepth understanding of the workings of power and women's violence against women in those societies. The insights can be juxtaposed with those emerging from this study and this will facilitate a better understanding of women's experience of violence exacted by other women in marriage in rural Ghana. As well, it can be a useful source of resources for policy and advocacy that is sensitive, and also informed by the specific experiences of women in both matrilineal and patrilineal societies in Ghana.

\section{Footnotes}

1 Since Edward Evans-Pritchard's (1976) influential work on the pervasiveness of the belief in supernatural forces amongst the Azande people of Sudan, there have been many studies on this subject matter. More recent ones include the writings of Jean Comaroff and John Comaroff (1993, 1999) and Peter Geschiere (1997, 2013).

${ }^{2}$ Appropriate institutional ethical clearance was secured for this research. In line with good ethnographical practice, pseudonyms have been used to protect my study's participants.

${ }^{3}$ Money required for adultery purification rites.

${ }^{4} \mathrm{~A}$ perceived mystical sickness linked to adultery.

${ }^{5}$ A commonly used phrase of derma sogla, evil mother-in-law was often evoked as women joked about this form of violence.

${ }^{6}$ These often included depriving the women of food, and even access to the kitchen to prepare food, access to the husband and also to productive resources such as shea nuts and the locus beans.

${ }^{7}$ For instance, Straus et al. (1980) found that the victim of violence in a North American family depends on whether the woman or the man is the dominant one in the relationship.

${ }^{8}$ Meal made of beans flour.

${ }^{9}$ In the Dagaaba settings shea nuts and dawadawa are the main sources of income for most women.

10 In an interview with Kanyinima's co-wife after their husband died and when she too had remarried another woman's husband, I asked her about this and she admitted abusing her on occasion out of anger.

\section{References}

Adinkrah, M. (2004). Witchcraft accusations and female homicide victimization in contemporary Ghana. Violence Against Women, 4(10), pp. 325-356.

Adu-Gyamfi, E. (2014). Challenges undermining domestic violence victims' access to justice in Mampong Municipality of Ghana. Journal of Law, Policy and Globalization, 27, pp. 75-90.

Amadiume, I. (1997). Reinventing Africa: Matriarchy, Religion and Culture. London: Zed Books.

Amoakohene, M. (2004). Violence against women in Ghana: A look at women's perceptions and review 
of policy and social responses. Social Science and Medicine, 59(11), 2373-2385.

Akurugu, C.A. (2019). Gender performativity in rural northern Ghana: Implications for transnational feminist theorising. Feminist Theory. Doi:10.1177/1464700119881308.

Akurugu, C.A. (2020). Performing Power in a mystical context: Implications for theorizing women's agency. Hypatia, 35, 549-566. Doi:10.1017/hyp.2020.30.

Ardayfio-Schandorf, E. (2005). Violence against women: The Ghanaian case. World Health, 11-4.

Akurugu, C.A. (2017). Marriage, power and performativity: Theorising gender relations in rural northern Ghana (Unpublished dissertation). Newcastle University.

Bleek, W. (1976). Witchcraft, gossip and death: A social drama. Man, pp. 526-541.

Butler, J. (2011). Bodies that matter: On the discursive limits of "sex". London: Routledge.

Cantalupo, N., Martin, L. V., Pak, K., \& Shin, S. (2006). Domestic violence in Ghana: The open secret. Georgetown Journal of Gender and the Law, 7, pp. 531-597.

Clifford, J., \& Marcus, G. E. (Eds.). (1986). Writing Culture: The Poetics and Politics of Ethnography; Edited by James Clifford, George E. Marcus. Berkeley: University of California Press.

Coker-Appiah, D., \& Cusack, K. (Eds.). (1999). Breaking the silence and challenging the myths of violence against women and children in Ghana: Report of a national study on violence. Accra, Ghana: Gender Research and Human Rights Documentation Centre.

Comaroff, J. John, (Eds.) (1993). Modernity and its malcontents: Ritual and power in postcolonial Africa. University of Chicago Press.

Comaroff, J., \& Comaroff, J. L. (1999). Occult economies and the violence of abstraction: Notes from the South African postcolony. American ethnologist, 26(2), pp. 279-303.

Dobash, R. \& Dobash, E. (1979). Violence against wives: A case against the patriarchy. New York: Free Press.

Dobash, R. P., Dobash, R. E., Wilson, M., \& Daly, M. (1992). The myth of sexual symmetry in marital violence. Social problems, 39(1), pp. 71-91.

Evans-Pritchard, E. E. (1976). Witchcraft, oracles and magic among the Azande. Vol. 12. London: Oxford.

Foucault, M. (1982). The subject and power. Critical inquiry, 8(4), pp. 777-795.

Gelles, R. J. (1985). Family violence. Annual review of sociology, 11(1), pp. 347-367.

Gelles, R. J. (1997). Intimate violence in families. Sage.

Geschiere, P. (1997). The Modernity of Witchcraft: politics and the occult in postcolonial Africa. University of Virginia Press.

Geschiere, P. (2013). Witchcraft, Intimacy, and Trust: Africa in Comparison. Chicago: The University of Chicago Press.

Ghana. Statistical Service (2012). 2010 population and housing census. Summary report of final results. Retrieved from

https://www.statsghana.gov.gh/gssmain/storage/img/marqueeupdater/Census2010_Summary_report_of _final_results.pdf

Institute of Development Studies, Ghana Statistical Services and Associates (2016). Domestic Violence in Ghana: Incidence, Attitudes, Determinants and Consequences. Brighton: IDS.

Johnson, M. P. (1995). Patriarchal terrorism and common couple violence: Two forms of violence against women. Journal of Marriage and the Family, pp. 283-294.

Johnson, M. P. (2008). A typology of domestic violence: Intimate terrorism, violent resistance, and situational couple violence. Boston: Northeastern University Press.

Kpiebaya, G. E. (1991). Dagaaba traditional marriage and family life. Wa, Ghana: Catholic Press.

Kurz, D. (1989). Social science perspectives on wife abuse: Current debates and future directions. Gender and Society, 3(4), pp. 489-505.

Meyers, D. T. (2000). Feminism and women's autonomy: The challenge of female genital cutting. Metaphilosophy, 31(5), pp. 469-491.

Mills, S. (2003). Michel Foucault. London and New York: Routledge.

Naaeke, A. Y. (2006). Breaking the silence about domestic violence: communication for development in northwestern Ghana. Gender and Behaviour, 4(2), pp. 782-796.

Nukunya, G. K. (2003). Tradition and change in Ghana: An introduction to sociology. Ghana Universities Press.

Ofei-Aboagye, R. O. (1994a). Altering the strands of the fabric: A preliminary look at domestic violence in Ghana. Signs: Journal of Women in Culture and Society, 19(4), pp. 924-938.

Ofei-Aboagye, R. O. (1994b). Domestic Violence in Ghana: An Initial Step. Columbia Journal of Gender and Law, 4, pp.1-25. 
Osam, S. (2004). Violence against women in Ghana: An analysis of cases presented in the print media. Ghana: ABANTU for Development.

Pappoe, M. E., \& Ardayfio-Schandorf, E. (1998). Dimension and consequences of violence against women in Ghana. Study Report Part I.

Pence, E., Paymar, M., \& Ritmeester, T. (1993). Education groups for men who batter: The Duluth model. Springer Publishing Company.

Skeggs, B. (2001). Feminist ethnography. In P. Atkinson, A. Coffey, S. Delamont, J. Lofland \& L. Lofland (Eds.), Handbook of ethnography (pp. 426-442). London: Sage.

Stacey, J. (1988). Can there be a feminist ethnography? Women's studies international forum, 11(1). Pergamon.

Straus, Murray A., \& Richard J. Gelles. (2017). Societal change and change in family violence from 1975 to 1985 as revealed by two national surveys. Physical violence in American families. Routledge, pp. 113-132.

Straus, M., Gelles, R. \& Steinmetz, S. (Eds). (1980). Behind closed doors: Violence in the American family. New York: Anchor Press/Doubleday.

Tjaden, P. \& Thoennes, N. (2000). Prevalence and consequences of male-to-female and female-tomale intimate partner violence as measured by the National Violence Against Women Survey. Violence against women, 6(2), pp. 142-161.

United Nations General Assembly. (1979). Convention on the elimination of all forms of discrimination against women. UN. Retrieved from: http://www.bayefsky.com/general/cedaw_c_2006_ii_4.pdf

Watts, C. \& Zimmerman, C. (2002). Violence against women: Global scope and magnitude. The lancet 359(9313), pp.1232-1237. 